\title{
Optimization of the conditions for producing soy protein isolate films
}

\author{
Isabela dos Santos Paglione', Marcella Vitoria Galindo², Karen Cristine de Souza', Fabio Yamashita ${ }^{3}$, \\ Carlos Raimundo Ferreira Grosso', Lyssa Setsuko Sakanaka', Marianne Ayumi Shirai"*
}

${ }^{1}$ Programa de Pós-graduação em Tecnologia de Alimentos (PPGTAL), Universidade Tecnológica Federal do Paraná, Avenida dos Pioneiros 3131, CEP 86036-370, Londrina, Paraná, Brazil, '²Departamento Acadêmico de Alimentos (DAALM), Universidade Tecnológica Federal do Paraná, Londrina, Paraná, Brazil, ${ }^{3}$ Programa de Pós-graduação em Ciência de Alimentos, Universidade Estadual de Londrina, Londrina, Paraná, Brazil

\section{A B S T R A C T}

The soy protein isolate (SPI) is a biopolymer highlighted as a raw material for producing films and demands the investigation of the processing conditions that make it possible to obtain a film with adequate functional properties. The objective of this work was to evaluate the effect of the $\mathrm{pH}$ and concentration of SPI on the mechanical properties, water vapor permeability, solubility, and color of the SPI films produced by casting using a central composite rotational design (CCRD). In general, the films presented a yellow coloration with a continuous aspect, good handling, and no apparent glycerol migration. The linear effect of pH positively influenced the tensile strength (TS) and elongation at break $(E L O)$ of the film $(p<0.05)$ but negatively influence the solubility $(S O L)$ and color parameter $L^{*}$ for which we obtained lower values of $\mathrm{SOL}$ and $\mathrm{L}^{*}$ at a high $\mathrm{pH}$. This possibly occurred because of the denaturation of the soy proteins at an alkaline $\mathrm{pH}$, far from the isoelectric point, resulting in their unfolding and solubilization which facilitated the interaction between the chains, forming a more compact structure. Considering the optimization by the desirability function, to obtain a film with high TS and ELO and low SOL, it is necessary to use $7.56 \mathrm{~g} / 100 \mathrm{~g}$ of SPI film-forming solution and to adjust the film-producing solution to $\mathrm{pH} 10.54$.

Keywords: Central composite rotational design; Biopolymers; Mechanical properties; Solubility; Desirability

\section{INTRODUCTION}

Soybean (Glycine max L. Merrill) is the oilseed crop most dominant in global trade, and Brazil is the second largest producer with a production of 117 million tons in the years of 2017/2018 (USDA, 2018). The most significant

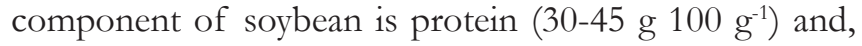
based on its content, soybean is commercially available as soybean meal (50-59\% protein), soy protein concentrate (65-72\% protein), and soy protein isolate ( $>90 \%$ protein) (Tian et al., 2018).

The soy protein isolate (SPI) is prepared from defatted soybean meal, which is a byproduct of soybean oil processing (Han et al., 2018; Wang et al., 2016). It consists of a mixture of proteins in which $90 \%$ are globulins. The most substantial fractions of globulins are the fraction 7S ( $\beta$-conglycinin) and 11S (glycinin), which correspond to approximately 37 and $31 \%$, respectively, of the total proteins extracted. Due to its structure, the SPI presents excellent functional properties regarding its capacities for gelling, emulsifying, and oil retention capacity in water (Nishinari et al., 2014), thus being considered a potential raw material for producing biodegradable edible films.

Many authors conducted studies on the production and characterization of SPI-based films (Carpiné et al., 2015; Carpiné et al., 2016; Han et al., 2018; Nandane and Jain, 2014). These films are generally yellowish, flexible, present an excellent oxygen barrier, and serve as a matrix for the incorporation of bioactive compounds. However, they are sensitive to moisture and therefore have a low barrier to water vapor (McHugh et al., 1994; Miller and Krochta, 1997; Perez-Gago et al., 1999).

The SPI films are usually produced by using a casting technique, which involves drying a complex colloidal solution consisting of protein, solvent, and plasticizer,

\footnotetext{
${ }^{*}$ Corresponding author:

Marianne Ayumi Shirai, Programa de Pós-graduação em Tecnologia de Alimentos (PPGTAL), Universidade Tecnológica Federal do Paraná, Avenida dos Pioneiros 3131, CEP 86036-370, Londrina, Paraná, Brazil. E-mail: marianneshirai@utfpr.edu.br

Received: 01 February 2019; Accepted: 12 April 2019
} 
previously spread on an appropriate support (Denavi et al., 2009). The formation of protein films has been possible at $\mathrm{pHs}$ far from their isoelectric point $(\mathrm{pI}=4.5)$ since, in the $\mathrm{pI}$, the coagulation hinders the formation of a homogeneous and compact matrix (Perez-Gago et al., 1999). The use of heat $\left(80-90^{\circ} \mathrm{C}\right)$ is also required to partially denature the protein, cleaving native disulfide bonds and exposing the sulfhydryl and hydrophobic groups to promote the formation of new bonds between the protein chains (Rhim and Lee, 2004). However, at high temperatures (above $90^{\circ} \mathrm{C}$ ), hydrophobic interactions can promote the polymerization and insolubilization of soy proteins, preventing the formation of the film (Jiang et al., 2012).

We verified in a previous study that the concentration of SPI and glycerol interfered in the mechanical properties of the film (Nandane and Jain, 2014). The increase in the concentration of SPI was related to an increase in the tensile strength and decrease in the elongation at break. On the other hand, the increase in the concentration of glycerol in the films decreased the tensile strength and increased the elongation at break. Due to several factors ( $\mathrm{pH}$, temperature, SPI concentration, and plasticizer) that may interfere with the production and properties of the SPI films, the objective of this study was to optimize the production of SPI films, evaluating the effect of the concentration of soy protein isolate (SPI) and $\mathrm{pH}$ on their mechanical properties, water vapor permeability, solubility, and color.

\section{MATERIAL AND METHODS}

\section{Material}

For producing the films, soy protein isolate $(>90 \%$ protein, Bremil, Brazil), glycerol (Synth, Brazil), sodium hydroxide
(Vetec, Brazil), and hydrochloric acid (Synth, Brazil) were used.

\section{Elaboration of the SPI films}

The SPI films were prepared using the casting method according Carpiné et al. (2015) with some modifications. The SPI (4.38 to $8.62 \mathrm{~g} / 100 \mathrm{~g}$ of film-forming solution) and glycerol (30 $\mathrm{g}$ glycerol/100 $\mathrm{g}$ of SPI) were solubilized in distilled water for 20 minutes on a magnetic stirrer. The solution was heated to $40^{\circ} \mathrm{C}$, then the $\mathrm{pH}$ of the solution was adjusted to $10.5(\mathrm{NaOH} 1 \mathrm{M})$, kept under stirring for 30 minutes, heated to $70^{\circ} \mathrm{C}$ and maintained at this temperature for an additional 20 minutes. The film-forming solution was cooled to $35^{\circ} \mathrm{C}$ and the $\mathrm{pH}$ was adjusted as indicated in Table 1 using $1 \mathrm{M} \mathrm{HCl}$. The film-forming solution was later homogenized in Ultraturrax (IKA, T 18 model, USA) at 10,000 rpm for 3 minutes. Subsequently, approximately $60 \mathrm{~g}$ of the film-forming solution was poured into acrylic plates $(21 \times 11 \mathrm{~cm})$, dried in incubator at $25^{\circ} \mathrm{C}$ and $45 \%$ RH for 24 hours. The films were stored in a desiccator at $25^{\circ} \mathrm{C}$ and $53 \% \mathrm{RH}$ for 48 hours before conducting the characterization. The Fig 1 shows some steps of the production of the SPI film.

The effect of SPI concentration (from 4.38 to $8.62 \mathrm{~g} / 100 \mathrm{~g}$ of film-forming solution) and $\mathrm{pH}$ (3.46 to 10.54) on the films properties was evaluated using a second order composite central rotational design (CCRD) with two independent variables, three variation levels, three replicates at the central point, totalizing 11 assays (Table 1).

\section{Characterization of the films Mechanical properties}

The tensile test was conducted using a texturometer according to the methods and standards of the American Society for Testing and Material (ASTM, 2012). The specimens were fixed to the movable jaws of the equipment

Table 1: Central composite rotational design with values of the factors and responses to mechanical properties, solubility, WVP and color

\begin{tabular}{|c|c|c|c|c|c|c|c|c|c|c|}
\hline \multirow[b]{2}{*}{ Run } & \multicolumn{2}{|c|}{ Factors } & \multicolumn{8}{|c|}{ Responses } \\
\hline & $\mathrm{pH}$ & SPI ${ }^{a}$ & $\mathrm{~T}$ (MPa) & ELO (\%) & YM (MPa) & SOL (\%) & $\begin{array}{c}\text { WVP x } \\
10^{-7} \text { (g/h.m.Pa) }\end{array}$ & $L^{*}$ & $a^{*}$ & $\mathbf{b}^{*}$ \\
\hline 1 & $4.50(-1)$ & $5.00(-1)$ & $2.5 \pm 1.0$ & $74.1 \pm 19.9$ & $48.5 \pm 18.5$ & $22.12 \pm 2.22$ & $1.42 \pm 0.63$ & $77.56 \pm 0.71$ & $-0.16 \pm 0.42$ & $34.60 \pm 1.05$ \\
\hline 2 & $4.50(-1)$ & $8.00(1)$ & $2.4 \pm 0.8$ & $123.9 \pm 45.8$ & $47.2 \pm 14.9$ & $24.46 \pm 0.25$ & $1.68 \pm 0.49$ & $78.58 \pm 1.42$ & $-0.62 \pm 0.97$ & $34.60 \pm 1.22$ \\
\hline 3 & $9.50(1)$ & $5.00(-1)$ & $3.6 \pm 0.2$ & $260.3 \pm 34.3$ & $68.6 \pm 13.2$ & $27.23 \pm 1.16$ & $1.12 \pm 0.06$ & $69.85 \pm 2.71$ & $1.45 \pm 1.45$ & $37.11 \pm 1.29$ \\
\hline 4 & $9.50(1)$ & $8.00(1)$ & $3.1 \pm 0.3$ & $369.3 \pm 74.4$ & $37.0 \pm 12.2$ & $22.12 \pm 1.36$ & $3.49 \pm 0.35$ & $69.14 \pm 0.77$ & $1.45 \pm 0.35$ & $36.85 \pm 0.31$ \\
\hline 5 & $3.46(-\alpha)$ & $6.50(0)$ & $2.4 \pm 0.1$ & $169.2 \pm 18.4$ & $46.6 \pm 3.2$ & $22.76 \pm 0.76$ & $3.66 \pm 0.32$ & $74.63 \pm 1.03$ & $1.61 \pm 0.61$ & $37.52 \pm 0.79$ \\
\hline 6 & $10.54(\alpha)$ & $6.50(0)$ & $4.2 \pm 0.9$ & $363.8 \pm 66.2$ & $65.6 \pm 8.6$ & $25.49 \pm 0.22$ & $4.05 \pm 0.31$ & $66.61 \pm 1.35$ & $2.82 \pm 0.64$ & $36.38 \pm 0.87$ \\
\hline 7 & $7.00(0)$ & $4.38(-\alpha)$ & $2.6 \pm 0.3$ & $204.2 \pm 40.4$ & $44.9 \pm 5.6$ & $25.85 \pm 0.36$ & $1.74 \pm 0.26$ & $69.63 \pm 5.83$ & $2.37 \pm 1.96$ & $34.06 \pm 1.29$ \\
\hline 8 & $7.00(0)$ & $8.62(\alpha)$ & $3.6 \pm 0.3$ & $236.2 \pm 36.8$ & $73.5 \pm 9.2$ & $25.83 \pm 0.59$ & $3.91 \pm 0.55$ & $71.92 \pm 1.83$ & $1.38 \pm 1.00$ & $34.29 \pm 0.69$ \\
\hline 9 & $7.00(0)$ & $6.50(0)$ & $3.4 \pm 0.4$ & $213.4 \pm 29.5$ & $70.2 \pm 8.9$ & $22.28 \pm 1.99$ & $1.82 \pm 0.89$ & $71.53 \pm 1.57$ & $1.42 \pm 0.62$ & $34.80 \pm 0.56$ \\
\hline 10 & $7.00(0)$ & $6.50(0)$ & $3.2 \pm 0.4$ & $236.3 \pm 34.2$ & $66.7 \pm 9.2$ & $22.13 \pm 1.51$ & $5.12 \pm 0.89$ & $68.75 \pm 2.34$ & $3.27 \pm 1.11$ & $36.15 \pm 0.27$ \\
\hline 11 & $7.00(0)$ & $6.50(0)$ & $3.3 \pm 0.7$ & $301.4 \pm 39.9$ & $62.9 \pm 19.7$ & $22.98 \pm 1.25$ & $4.08 \pm 0.95$ & $71.38 \pm 3.47$ & $2.07 \pm 1.72$ & $35.14 \pm 1.54$ \\
\hline
\end{tabular}

Soybea protein isolated (IPS). Elongation at break (ELO). Young $\times \mathrm{s}$ modulus (MY). Tensile strenght (T); Solubility (SOL); Water vapor permeability (WVP); ${ }^{a}(g / 100 g$ solution). 

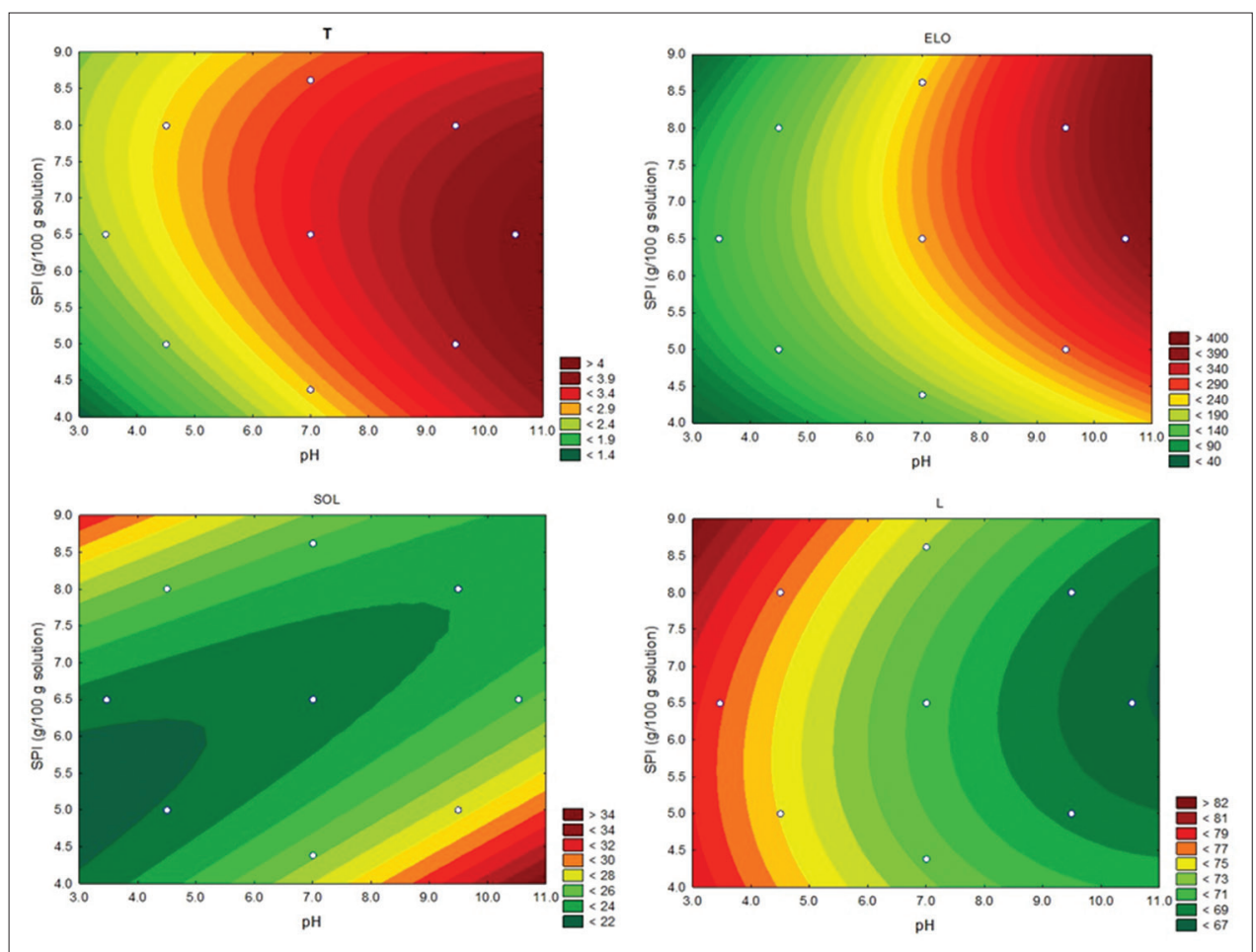

Fig 1. Production of the SPI film by casting.

with an initial distance of $30 \mathrm{~mm}$ and cross-head speed of $0.8 \mathrm{~mm} / \mathrm{s}$. The maximum tensile strength (MPa), elongation at break (\%), and modulus of elasticity or Young's modulus $(\mathrm{MPa})$ were determined.

\section{Water vapor permeability}

The water vapor permeability was determined by gravimetric method in triplicate according E96-00 American Society for Testing and Material method (ASTM, 2000) at $25^{\circ} \mathrm{C}$.

\section{Color measurement}

The color was measured using a KONICA MINOLTA colorimeter and ten random measurements on the surface of the films were conducted, which provided the parameters L* brightness (black-white), a* (green - red), and $\mathrm{b}^{*}$ (blue - yellow).

\section{Solubility in water}

The films' solubility in water was determined according method described by (Gontard et al., 1994). The water solubility was obtained by the percentage of dry material of the film solubilized in water.

\section{Scanning electron microscopy}

It was possible to obtain the SEM image only from the optimized film formulation. The film was previously dried in a desiccator containing silica gel for 14 days and later fractured in liquid nitrogen and fixed on stubs with carbon ribbons. The sample was covered with gold using a Sputter Coater and then visualized in a scanning electron microscope with acceleration power of $20 \mathrm{kV}$ for surface and fracture analyses. A magnification of $1600 \mathrm{x}$ was used for the fracture area and $400 \mathrm{x}$ for the surface.

\section{Statistical analysis}

The CCRD was used to evaluate the effect of the concentration of SPI and the $\mathrm{pH}$ on the properties of the film: color ( $L^{*}, a^{*}$, and $\left.b^{*}\right)$, water vapor permeability (WVP), solubility (SOL), maximum tensile strength (TS), elongation at break (ELO), and modulus of elasticity or Young's modulus (YM). The polynomial models for each response was adjusted using the STATISTICA ${ }^{\circledR}$ program (StatSoft, Tulsa, USA), version 10. The mathematical model was:

$$
\begin{aligned}
Y & =b_{0}+b_{1} X_{1}+b_{2} X_{2}+b_{11} X_{1}^{2}+b_{22} X_{2}^{2} \\
& +b_{12} X_{1} X_{2}
\end{aligned}
$$

Where $\mathrm{Y}$ is the response; $\mathrm{b}_{0}$ is the mean value, $\mathrm{b}_{1}$ and $\mathrm{b}_{2}$ are the coefficients of regression for the linear effects; $b_{11}$ and $b_{22}$ are the coefficients of regression for the quadratic effects; $b_{12}$ is the coefficient of regression for the interaction effect; and $X_{1}$ and $X_{2}$ are the independent variables. The analysis of variance ANOVA (5\% of significance) was conducted to evaluate the level of significance, the coefficient of determination $\left(\mathrm{R}^{2}\right)$, and the lack of adjustment of the mathematic models for each response.

Finally, the film formulation was optimized using the desirability function (multi-response optimization) 
considering the properties TS, ELO, and SOL. The high values of TS and ELO and low value of SOL were considered desirable to obtain a good SPI film. The SPI film under optimal conditions was prepared and characterized regarding mechanical properties, solubility, WVP, color, and SEM.

\section{RESULTS AND DISCUSSION}

The SPI films presented a mean thickness of $217 \pm 40 \mu \mathrm{m}$, were easily removed from the acrylic plates, showed a continuous, yellowish color, good handling, and no apparent glycerol migration.

\section{Mechanical properties}

Table 1 shows the experimental results of the mechanical properties of the SPI films according to the condition established in the CCRD. Table 2 shows the coefficients of regression and analysis of variance of the mathematical models for these responses.

The mean tensile strength (TS) of the SPI films ranged from $2.4 \pm 0.1$ to $4.2 \pm 0.9 \mathrm{MPa}$, with similar values reported by Jiang et al. (2012), $2.21 \pm 0.25$ to $6.03 \pm 0.35 \mathrm{MPa}$. According to Table 2 and Fig 2, the linear effect of the $\mathrm{pH}$ influenced the TS of the film indicating that the higher the $\mathrm{pH}$ of the film, the higher the TS is. The same behavior was described by Cho et al. (2007) who reported that the TS of the SPI films increased with increase in the $\mathrm{pH}$ to 7 and above $(8,9$, and 10$)$, the increase considered not significant.

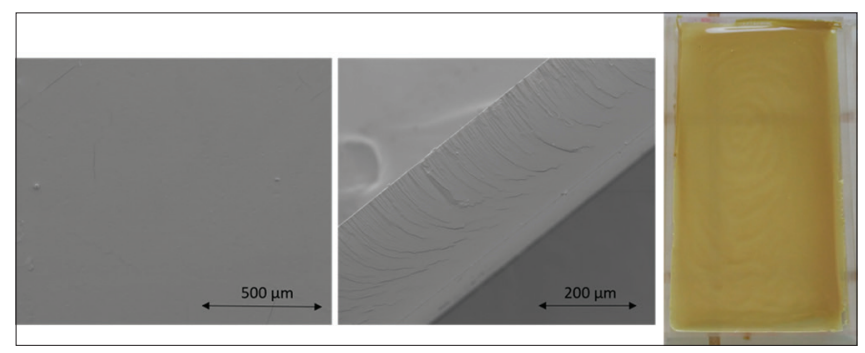

Fig 2. Contour surface of the influence of $\mathrm{pH}$ and SPI concentration on tensile strength $(\mathrm{T})$, elongation at break (ELO), solubility (SOL), and luminosity $\left(\mathrm{L}^{*}\right)$ of the SPI films.
Perez-Gago et al. (1999) observed the same behavior as Cho et al. (2007), as well as that the films without heat treatment presented lower TS than films that were heated $\left(90^{\circ} \mathrm{C}\right.$ for $\left.30 \mathrm{~min}\right)$. Jiang et al. (2012) also observed that heat treatment at temperatures below $90^{\circ} \mathrm{C}$ was essential to obtain films with high TS, regardless of $\mathrm{pH}$.

The elongation at rupture is a measure of the elasticity of the film and refers to the maximum change in film length before breaking (Nandane and Jain, 2014). The SPI films from this work presented ELO from 74.1 to $369.3 \%$. These values are comparable to synthetic films such as low-density $(100-700 \%)$ and high density (100 - 1000\%) polyethylene, presenting values superior to cassava, corn, potato, and wheat starch films developed by Leites Luchese et al. (2017) whose values ranged from 41 to $166 \%$. As verified for TS, the linear effect of the $\mathrm{pH}$ significantly influenced the elongation at break (ELO) of the film, that is, the higher the $\mathrm{pH}$, the more flexible the film was. The same behavior was observed by Cho et al. (2007), who describe that the ELO of the SPI films differs with the changes in $\mathrm{pH}$ values showing more flexibility at the alkaline $\mathrm{pH}$ of 12 . This occurred because the treatment with alkaline $\mathrm{pH}$ causes the dissociation of the SPI soluble subunits that aggregate forming soluble proteins (Jiang et al., 2010) which appears to be conducive to the formation of a stable network.

The Young's modulus (YM) indicates the rigidity of the material and describes how the mechanical properties of the film relate to the chemical structure of the biopolymers (Nandane and Jain, 2014). The mean values of YM in this work ranged from 37.0 to $73.5 \mathrm{MPa}$. The coefficient of determination was low $\left(\mathrm{R}^{2}=0.48\right)$, indicating that the generated model explains only $48 \%$ of the observed data variation.

In general, the $\mathrm{pH}$ had a significant effect on the mechanical properties, indicating that higher values provide films with higher TS, ELO, and YM. The improvement in the filmforming capacity at alkaline $\mathrm{pHs}$, far from the isoelectric point, occurred because the denaturation of the soy proteins was promoted and resulted in the unfolding and

Table 2: Regression coefficients and analysis of variance (ANOVA) for variables T, ELO, YM, SOL, WVP, $L^{*}, a^{*}$ and $b^{*}$

\begin{tabular}{lcccccccc}
\hline Coefficients & RT (MPa) & ELO (\%) & YM (MPa) & SOL (\%) & WVP (g/m.h.Pa) & L $^{*}$ & $\mathbf{a}^{*}$ & $\mathbf{b}^{*}$ \\
\hline Mean & 3.31 & 224.82 & 66.62 & 22.46 & $3.67 \times 10^{-7}$ & 70.55 & 2.26 & 35.36 \\
pH (L) & $0.54^{*}$ & $88.35^{*}$ & 4.58 & $0.83^{*}$ & $0.26 \times 10^{-7}$ & $-3.56^{*}$ & 0.67 & 0.39 \\
pH (Q) & -0.07 & 11.74 & $-7.1^{*}$ & 0.58 & $-0.26 \times 10^{-7}$ & 0.80 & -0.39 & 0.84 \\
IPS (L) & 0.10 & 25.52 & 0.95 & -0.35 & $0.71 \times 10^{-7}$ & 0.44 & -0.23 & 0.01 \\
IPS (Q) & -0.19 & -11.42 & -5.53 & $1.44^{*}$ & $-0.77 \times 10^{-7}$ & 0.88 & -0.57 & -0.53 \\
pH x IPS & -0.11 & 14.80 & -7.56 & $-1.86^{*}$ & $0.52 \times 10^{-7}$ & -0.43 & 0.11 & -0.06 \\
R $^{2}$ & 0.79 & 0.86 & 0.47 & 0.90 & 0.48 & 0.79 & 0.47 & 0.60 \\
Lack of fit & 0.71 & 7328.85 & $815.4^{*}$ & 3.09 & $5.69 \times 10^{-14}$ & 24.31 & 5.18 & 5.21 \\
\hline
\end{tabular}

Soybean protein isolate (SPI), tensile strenght (T), elongation at break (ELO), Young $\times \mathrm{s}$ modulus (YM). solubility (SOL). Water vapor permeability (WVP). *significant at $5 \%$ level $(p<0.05)$. 
solubilization of the proteins that facilitated the interaction between the chains, forming a more compact structure (Jiang et al., 2009; Nishinari et al., 2014). According to Rhim et al. (2000), the SPI films prepared under alkaline conditions are stabilized mainly by disulfide bonds and, to a lesser extent, by hydrophobic and hydrogen bonds, indicating that the covalent bonds contribute most to the stability of this type of film. The models obtained for TS and ELO were adequate to verify the response tendency, a fact evidenced by the coefficient of determination values (0.79 and 0.90 respectively) and non-significant adjustment.

\section{Solubility and water vapor permeability}

The experimental results for solubility (SOL) and water vapor permeability (WVP) of the SPI films are presented in Table 1. In the solubility assay, all of the films remained intact after contact with water and shaking at $25^{\circ} \mathrm{C}$. The solubility was influenced by the quadratic effect of the $\mathrm{pH}$ and by the linear and quadratic effects of the concentration of the SPI, ranging from 22.12 to $27.23 \%$. We verified that the solubility of the films increased with increase in $\mathrm{pH}$ and SPI concentration values.

The increase in solubility related to the increase in the concentration of the SPI can be explained by the proportion of $58 \%$ of polar amino acids present in the soy protein. Such high polarity increases the affinity of the film for water, thus increasing the solubility of the film (Rhim and Lee, 2004). Similar results were observed by Rocha et al. (2014), who reported that the solubility of the film increased with the increase in protein content.

The increase in the value of the $\mathrm{pH}$ also favored the increase of the solubility of the film. This characteristic was explained by Rocha et al. (2014) as probably due to the distance of the isoelectric point $(\mathrm{pI})$ of the soy protein $(\mathrm{pH}$ 4.5), where the solubility is minimal. Gennadios et al. (1993) observed that the solubility of the protein increased under alkaline conditions when studying the $\mathrm{pH}$ action on wheat gluten and soy protein isolate. However, Cho et al. (2007) reported that the $\mathrm{pH}$ did not affect the solubility of the films in edible films produced from membrane-processed soy protein concentrate or SPI, possibly due to the higher temperature $\left(90^{\circ} \mathrm{C}\right)$ used for their production.

The interaction between the $\mathrm{pH}$ and SPI was also significant, indicating that, as presented in Fig 2, at a high $\mathrm{pH}$ and reduced concentration of SPI, and reduced $\mathrm{pH}$ and high concentration of SPI, higher solubility values tend to be obtained.

The values for WVP ranged from 1.12 to $5.12 \times 10^{-7} \mathrm{~g} / \mathrm{h} . \mathrm{m} . P a$. Values of the same order of magnitude were obtained by Carpiné et al. (2015) for SPI films added with coconut oil and natural surfactants (lecithin and Yucca schidigera), while Cho et al. (2007) reported higher values. As presented in Table 2, the adjusted model was incapable of explaining the effect of $\mathrm{pH}$ and SPI concentration on WVP, besides presenting a low coefficient of determination $\left(R^{2}=0.48\right)$. The same was described by Cho et al. (2007) who found no relation between the WVP and the change in the $\mathrm{pH}$ (acid and alkaline). Different results were described by Rocha et al. (2014), who reported the influence of the concentration of glycerol, $\mathrm{pH}$, the interaction between the SPI and $\mathrm{pH}$ on the WVP of the film. According to the authors, the WVP increased with the reduction of $\mathrm{pH}$, reduced only when using lower concentrations of SPI and alkaline $\mathrm{pH}$.

\section{Color measures}

The experimental results of the color measure expressed regarding $L^{*}, a^{*}$, and $b^{*}$ are summarized in Table 1 . The films presented $\mathrm{L}^{*}$ values ranging from 66.61 to 77.56 , $\mathrm{a}^{*}$ from -0.16 to 3.27 , and $b^{*}$ from 34.06 to 37.52 . Based on these values, we inferred the predominance of the yellow color, due to the higher values of $\mathrm{b}^{*}$ and high luminosity. For SPI films dried under different conditions, the yellow color (positive value for $\mathrm{b}^{*}$ ) was predominant, typical of films produced from soy protein (Denavi et al., 2009).

We observed that $\mathrm{L}^{*}$ was negatively influenced by the linear effect of the $\mathrm{pH}$, that is, the increase in $\mathrm{pH}$ caused a decrease in the luminosity of the film (Table 2). This occurred because of the denaturation of the protein at an alkaline $\mathrm{pH}$, favoring the formation of a more compact structure, which may have contributed to the opaque appearance of the film.

The models obtained in this work were unable to explain the behavior of the parameters $a^{*}$ and $b^{*}$, as can be observed by the low coefficient of determination and the lack of significance of the effects (Table 2).

\section{Optimization of the production of the SPI film by the desirability function}

To optimize the formulation of the SPI film, we considered its use as food packaging. Thus, it must have good mechanical strength, flexibility, and low solubility in water. We, therefore, established that to obtain a good film, a maximum TS and ELO and minimum SOL is desirable.

Thus, we sought the combination of these criteria through the mathematic models adjusted to the TS, ELO, and SOL responses to find the optimal values of the independent variables for the film production. The desirability consists of a function that simultaneously combines different optimized responses, demanding a specific desirable function for each response. The overall desirability is 


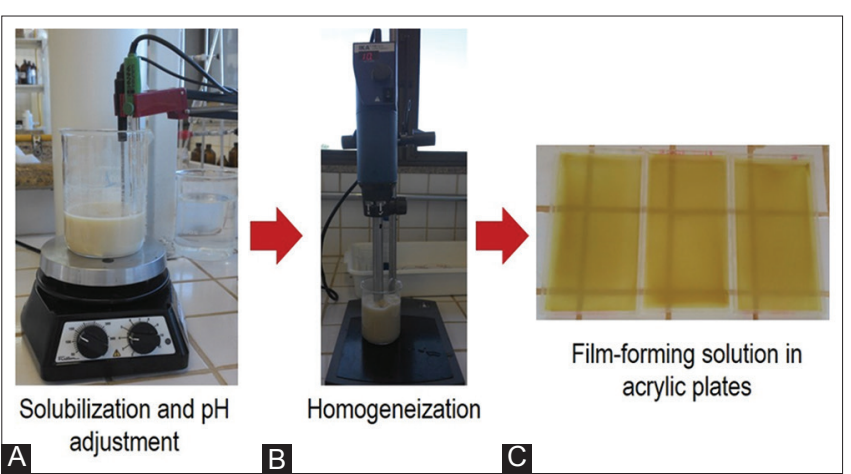

Figure 3. Scanning electron microscopy (surface and fracture, A and B) images and appearance (C) of the optimal SPI film.

commonly obtained through the average of the individual desirabilities previously defined.

In this work, the optimum conditions to produce the SPI films were of $7.56 \%$ SPI and $\mathrm{pH}$ of 10.54 . The optimum film presented average thickness of $184 \mu \mathrm{m}$, was easily removed from the acrylic plate, presented a continuous, yellowish color, good handling, and no apparent glycerol migration, as demonstrated in Fig 3. The optimization of achira flour (Andrade-Mahecha et al., 2012) and banana flour films (Pelissari et al., 2013) has also been successfully reported by desirability function.

Therefore, the optimum film presented the following characteristics: Elongation at break of $314.82 \pm 7.66 \%$; Young's elasticity modulus of $82.15 \pm 14.74 \mathrm{MPa}$; Tensile strength of $4.72 \pm 0.52$; Solubility of $25.88 \pm 1.7 \%$; WVP of $4.45 \times 10^{-7} \pm 0.85 \mathrm{~g} / \mathrm{m} . h . P a$; and L* of $66.96 \pm 2.95, \mathrm{a}^{*}$ of $2.38 \pm 0.87$, and $b^{*}$ of $37.32 \pm 0.92$. From the surface and fracture SEM image, we observed a homogeneous and compact structure, suggesting that the processing conditions were adequate for the solubilization and denaturation of SPI proteins.

\section{CONCLUSIONS}

This work demonstrated that the concentration of SPI and the $\mathrm{pH}$ used during the production significantly interfered in the final characteristics of the film. The increase in the concentration of SPI increased the solubility of the film, while the increase in the $\mathrm{pH}$ values caused an increase in the tensile strength and flexibility and decrease in the film's solubility in water. The mathematical models obtained in this work explained the solubility, the maximum tensile strength, the elongation at rupture, and the luminosity $\left(\mathrm{L}^{*}\right)$ with a good coefficient of determination. Considering the optimization by the desirability technique, an SPI of $7.56 \%$ and solution $\mathrm{pH}$ of 10.54 is necessary to produce a film with low solubility, high tensile strength, and high elongation at break.

\section{ACKNOWLEGMENTS}

The authors would like to thank CNPq for their financial support (process 445272/2014-7), Microscopy Laboratory of Universidade Estadual de Londrina (UEL) for scanning electron microscopy analysis, and Bremil for donating SPI sample.

\section{Authors' contributions}

I.S.P. performed the experiment, analyzed the data, conducted statistical data analysis and wrote the paper; M.V.G. and K.C.S. assisted in the data collection in the laboratory; F.Y. assisted in the statistical analyses; L.S.S and C.R.F.G. supported the design of the study and critically revised the paper conceived; M.A.S. wrote the paper and assumed primary responsibility for the final content. All the authors have read and approved the final manuscript.

\section{REFERENCES}

Andrade-Mahecha, M. M., D. R. Tapia-Blácido and F. C. Menegalli. 2012. Development and optimization of biodegradable films based on achira flour. Carbohydr. Polym. 88: 449-458.

ASTM Standard D882. 2012. Standard Test Method for Tensile Properties of Thin Plastic Sheeting. ASTM International, West Conshohocken, PA.

Carpiné, D., J. L. A. Dagostin, E. F. de Andrade, L. C. Bertan and M. R. Mafra. 2016. Effect of the natural surfactant Yucca schidigera extract on the properties of biodegradable emulsified films produced from soy protein isolate and coconut oil. Ind. Crops Prod. 83: 364-371.

Carpiné, D., J. L. A. Dagostin, L. C. Bertan and M. R. Mafra. 2015. Development and characterization of soy protein isolate emulsion-based edible films with added coconut oil for olive oil packaging: Barrier, mechanical, and thermal properties. Food Bioprocess Technol. 8: 1811-1823.

Cho, S. Y., J. W. Park, H. P. Batt and R. L. Thomas. 2007. Edible films made from membrane processed soy protein concentrates. LWT Food Sci. Technol. 40: 418-423.

Denavi, G., D. R. Tapia-Blácido, M. C. Añón, P. J. A. Sobral, A. N. Mauri and F. C. Menegalli. 2009. Effects of drying conditions on some physical properties of soy protein films. J. Food Eng. 90: 341-349.

Gennadios, A., A. H. Brandenburg, C. L. Weller and R. F. Testin. 1993. Effect of $\mathrm{pH}$ on properties of wheat gluten and soy protein isolate films. J. Agric. Food Chem. 41: 1835-1839.

Gontard, N., C. Duchez, J. L. Cuq and S. Guilbert. 1994. Edible composite films of wheat gluten and lipids: Water vapour permeability and other physical properties. Int. J. Food Sci Technol. 29: 39-50.

Han, Y., M. Yu and L. Wang. 2018. Preparation and characterization of antioxidant soy protein isolate films incorporating licorice residue extract. Food Hydrocoll. 75: 13-21.

Jiang, J., J. Chen and Y. L. Xiong. 2009. Structural and emulsifying properties of soy protein isolate subjected to acid and alkaline pH-shifting processes. J. Agric. Food Chem. 57: 7576-7583.

Jiang, J., Y. L. Xiong and J. Chen. 2010. pH shifting alters solubility characteristics and thermal stability of soy protein isolate and its globulin fractions in different $\mathrm{pH}$, salt concentration, and 
temperature conditions. J. Agric. Food Chem. 58: 8035-8042.

Jiang, J., Y. L. Xiong, M. C. Newman and G. K. Rentfrow. 2012. Structure-modifying alkaline and acidic $\mathrm{pH}$-shifting processes promote film formation of soy proteins. Food Chem. 132: 1944-1950.

Luchese, C. L., J. C. Spada and I. C. Tessaro. 2017. Starch content affects physicochemical properties of corn and cassava starchbased films. Ind. Crops Prod. 109: 619-626.

McHugh, T. H., J. F. Aujard and J. M. Krochta. 1994. Plasticized whey protein edible films: Water vapor permeability properties. J. Food Sci. 59: 416-419.

Miller, K. S. and J. M. Krochta. 1997. Oxygen and aroma barrier properties of edible films: A review. Trends Food Sci. Technol. 8: 228-237.

Nandane, A. S. and R. Jain. 2014. Study of mechanical properties of soy protein based edible film as affected by its composition and process parameters by using RSM. J. Food Sci. Technol. 52: 3645-3650.

Nishinari, K., Y. Fang, S. Guo and G. O. Phillips. 2014. Soy proteins: A review on composition, aggregation and emulsification. Food Hydrocoll. 39: 301-318.

Pelissari, F. M., M. M. Andrade-Mahecha, P. J. A. Sobral and F. C. Menegalli. 2013. Optimization of process conditions for the production of films based on the flour from plantain bananas
(Musa paradisiaca). LWT Food Sci. Technol. 52: 1-11.

Perez-Gago, M. B., P. Nadaud and J. M. Krochta. 1999. Water vapor permeability, solubility, and tensile properties of heat-denatured versus native whey protein films. J. Food Sci. 64: 1034-1037.

Rhim, J. W. and J. H. Lee. 2004. Effect of $\mathrm{CaCl}_{2}$ treatment on mechanical and moisture barrier properties of sodium alginate and soy protein-based films. Food Sci. Biotechnol. 13: 728-732.

Rhim, J. W., A. Gennadios, A. Handa, C. L. Weller and M. A. Hanna 2000. Solubility, tensile, and color properties of modified soy protein isolate films. J. Agric. Food Chem. 48: 4937-4941.

Rocha, G. O., M. G. Farias, C. W. P. de Carvalho, J. L. R. Ascheri and M. C. Galdeano. 2014. Filmes compostos biodegradáveis a base de amido de mandioca e proteína de soja. Polímeros 24: 587-595.

Tian, H., G. Guo, X. Fu, Y. Yao, L. Yuan and A. Xiang. 2018. Fabrication, properties and applications of soy-protein-based materials: A review. Int. J. Biol. Macromol. 120: 475-490.

USDA United States Department of Agriculture. 2018. Brazil: Oilseeds and Products Update. Available from: https://www.fas.usda.gov/ data/brazil-oilseeds-and-products-update-16. [Last retrieved on 2019 Feb 06].

Wang, H., D. Hu, Q. Ma and L. Wang. 2016. Physical and antioxidant properties of flexible soy protein isolate films by incorporating chestnut (Castanea mollissima) bur extracts. LWT Food Sci. Technol. 71: 33-39. 